\title{
Economic Records in the Corpus of Tangut Manuscripts
}

For generations, the main sources of knowledge and historical evidence on the Tangut economy were archives in the Chinese tradition, such as memorials and documents that court authorities and local officials had submitted to the Song, Liao and Jin emperors, as well as a range of literary works found in these regimes, which touch on the economic lives of the Tanguts. These materials, neither systematic nor 'primary' statistical records, are at best second-hand reports. The general lack of economic-historical sources resulted in tremendous obstacles to scholars interested in the economy of Western Xia.

Archaeology in the past century has yielded a considerable body of manuscripts dating back to the Tangut imperial period, all of which were recorded by the Tanguts themselves. Among them is the imperial law code of Xixia, which offers a wealth of information on the legal regulations of the empire's economy. Also excavated are social documents, such as household registers, accounts and contracts. These materials produced and maintained by the rulers and residents of Western Xia are authentic, reliable and worthy of historians' trust. They constitute the main corpus of primary resources, not only on the history of Tangut economic life and productions, but also on Western Xia, in general. Therefore, these sources deserve our special attention and appreciation.

\section{Economic Regulations in the Laws of Heavenly Prosperity}

The Laws of Heavenly Prosperity, first excavated in Khara-Khoto, is a comprehensive imperial law code compiled and revised during the reign of Emperor Renzong of Xia (1124-1193), based on existing materials from previous generations. As the fundamental legal document of the country, it set forth items of laws pertaining to the economic life.

\subsection{Compilation and Content of the Laws of Heavenly Prosperity}

The surviving copy of the legal text is the Tangut block-print edition of the work. As the majestic walls of Western Xia crumbled, the law code was also buried deep underground for as long as seven centuries. Today, it is preserved 
at the Institute of Oriental Manuscripts (IOM) in the Russian Academy of Sciences. Russian experts have conducted research on the text and translated it into Russian. In subsequent years, the original Tangut has also been translated into Chinese, supplemented with annotations and commentaries by Chinese scholars. But already in the Russian Collection of Khara-Khoto Manuscripts (1998), a complete and generally clear original text has been made accessible to the public. ${ }^{1}$

The Laws of Heavenly Prosperity is prefaced by a "Proclamation of Legislations," which details the historical facts about the revision, entitlement, carving and printing, imperial sanction and establishment of the laws. It bears a certain degree of resemblance to such similar Tang and Song documents as Zhangsun Wuji's 進疏律表 for the Tang Code and Dou Yi's 進刑統表 for the Compendium of the Song Laws, except that the latter two only mention the history of compilation and submission of the law code therein concerned, but nothing related to the enactment of the laws.

As suggested by the full title of the laws, the Revised and Newly Enacted Laws of Heavenly Prosperity, there had been laws in Western Xia prior to the birth of this monumental code. A series of references in the proclamatory preface, "with the meanings from the righteous and great laws," "by comparison between the old and new laws and orders," and "to conduct in accordance with the new law," reveal the pre-existence of laws before their eventual codification. It is further mentioned in the "Proclamation of Legislations" that 'obscurities, ambivalences and other confusions and obstacles' also demand revisions. In other words, the Tanguts amended their laws according to practical needs in order to render laws and regulations clear and consistent, and thus easier to enact and enforce. The excavation of the New Laws and the New Laws of Year Hai in Khara-Khoto alongside the Laws of Heavenly Prosperity shows that neither the codification nor the revision of laws was a one-time project.

The Laws of Heavenly Prosperity was compiled and edited by the Tangut royalty, Lord of the North and Central Secretary Weiming Dibao. A high-ranking official, he was probably the first premier of the court, but for some reason remains unspecified in Chinese archives. Amongst the editor-legislators under his directorship were up to nine affiliated officials in the Central Secretariat

1 Кычанов, Е.И. Измененный и заново утвержденный кодекс девиза царствования Небесное процветание (1149-1169). В 4-х кн. М.: Издательство «Наука», ГРВЛ, 1987-1989 (Памятники письменности Востока LXXXI, 1-4). Shi, Jinbo; Nie Hongyin; Bai Bin (eds.). The Laws of Heavenly Prosperity. Beijing: Science Press, 1994. Shi, Jinbo; Nie, Hongyin; Bai, Bin. Revised Laws of Heavenly Prosperity. Beijing: Law Press, 200o. For the original text, see also Shi, Wei and Kychanov (eds.). Russian Collection of Khara-Khoto Manuscripts Vol. viII. Vol. IX, pp. 1-52. 
and the Council of Military Affairs. Others included chiefs of bureaus, scholars and fellows of the imperial academy. Indeed, the project gathered the most authoritative political, cultural and literary figures of the time, and, even upon its completion, was not enacted until approved by Emperor Renzong himself.

Listed right after the authors of the "Proclamation of Legislations" are about four additional officials, imperial scholars and academicians, who joined the team not as editors but as Tangut-Chinese translators. It may be inferred from this arrangement that both Tangut and Chinese editions of the Laws of Heavenly Prosperity circulated in Western Xia, a fact marvellous but not strange, given that large communities of Han and Fan people in the Tangut regime would both have resorted to consulting the laws.

“Heavenly Prosperity” (Tangut: 酸歇 [ Đwor lji.j]; Chinese: 天盛), a period which lasted for 21 years, was the era-name of Emperor Renzong of Western Xia. Because no specific year or sexagenary cycle (stem-and-branch) is referred to in the Laws of Heavenly Prosperity, it is rather difficult to infer the exact time of its publication and enactment. But we know that the era of "Heavenly Prosperity" was about the time when the ambitious Ren Dejing entered the court, eventually divided up the country and sought his own ruin. This context of tense court politics sheds special light on possible reasons why the content of the Laws of Heavenly Prosperity emanates an ardent defense of imperial power. In addition to extremely harsh penalties for potentially subversive activities, the legal codex also restricts the eligibility of royal status to the Weiming clan, and stipulates that concerning office-holders at the same bureaucratic rank, the Fan (Qiangic Tanguts) always come before the Han (Chinese in the Central Plains). To the Han-ethnic Ren Dejing, these are formidable obstacles to his path of promotion and eventually, attempted usurpation. In fact, it is quite possible that the Laws of Heavenly Prosperity was enacted in the early years of Ren Dejing's tenure in the court, when he was still cultivating his political clout. The best we can do to pin down a specific time is to narrow it down to any point between the first year of the era (1149 AD) and the eighth year of "Heavenly Prosperity" - when Ren finally rose to the rank of Premiership. It is not rash to conclude, based on the list of legislating editors in charge of the Laws of Heavenly Prosperity, that the laws were the doings of the Weiming royalties: amongst the first nine titled officials, six enjoy the honour of the family name Weiming. Even in the entire crew of 19 editors, most are Dangxiang Tanguts, and not even one of them is from Ren's family. All the evidence seems to suggest that this revision was accomplished when the Tangut royalties had not yet been significantly weakened. 


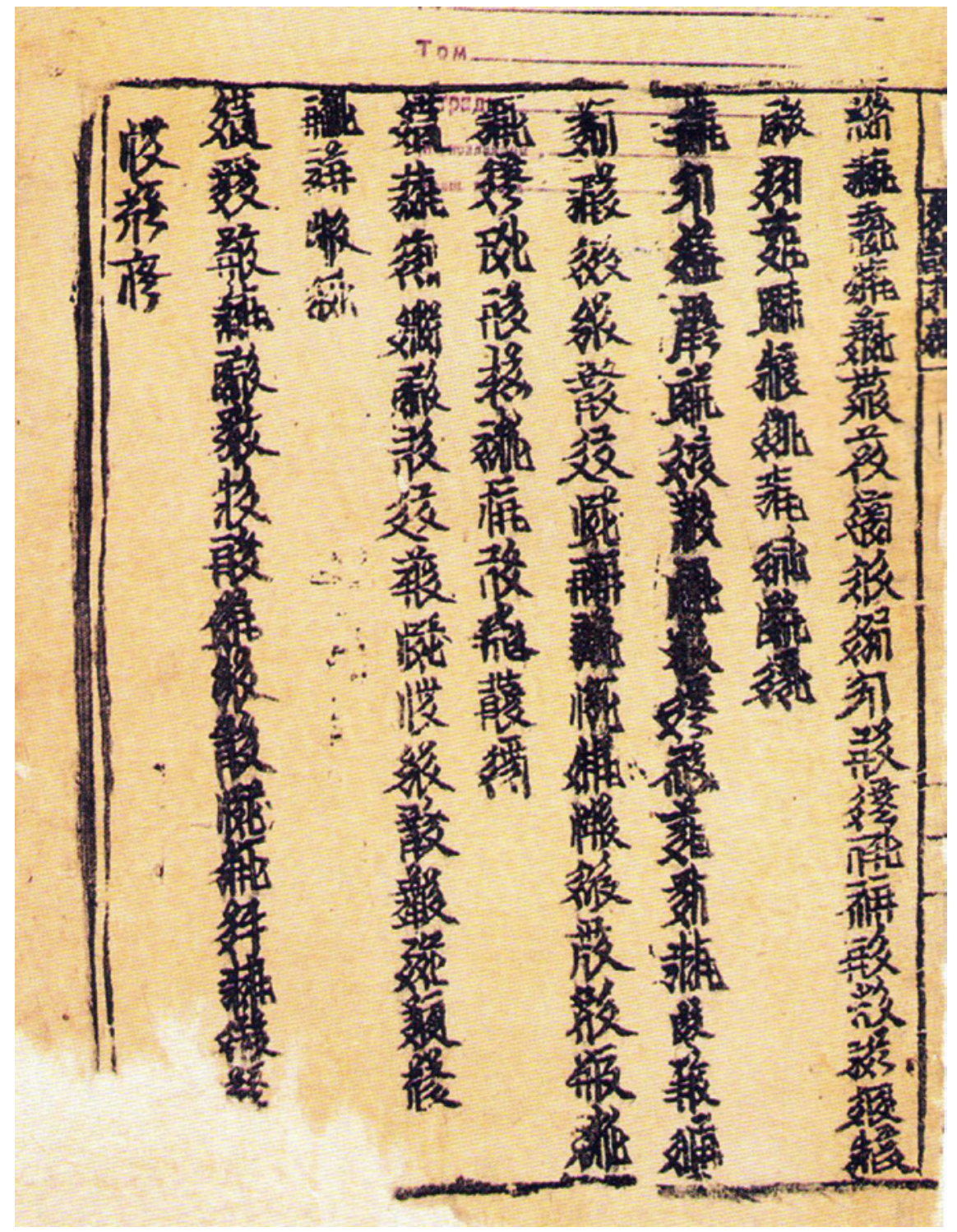

FIGURE 11 The "Proclamation of Legislations" in the Laws of Heavenly Prosperity (1) 


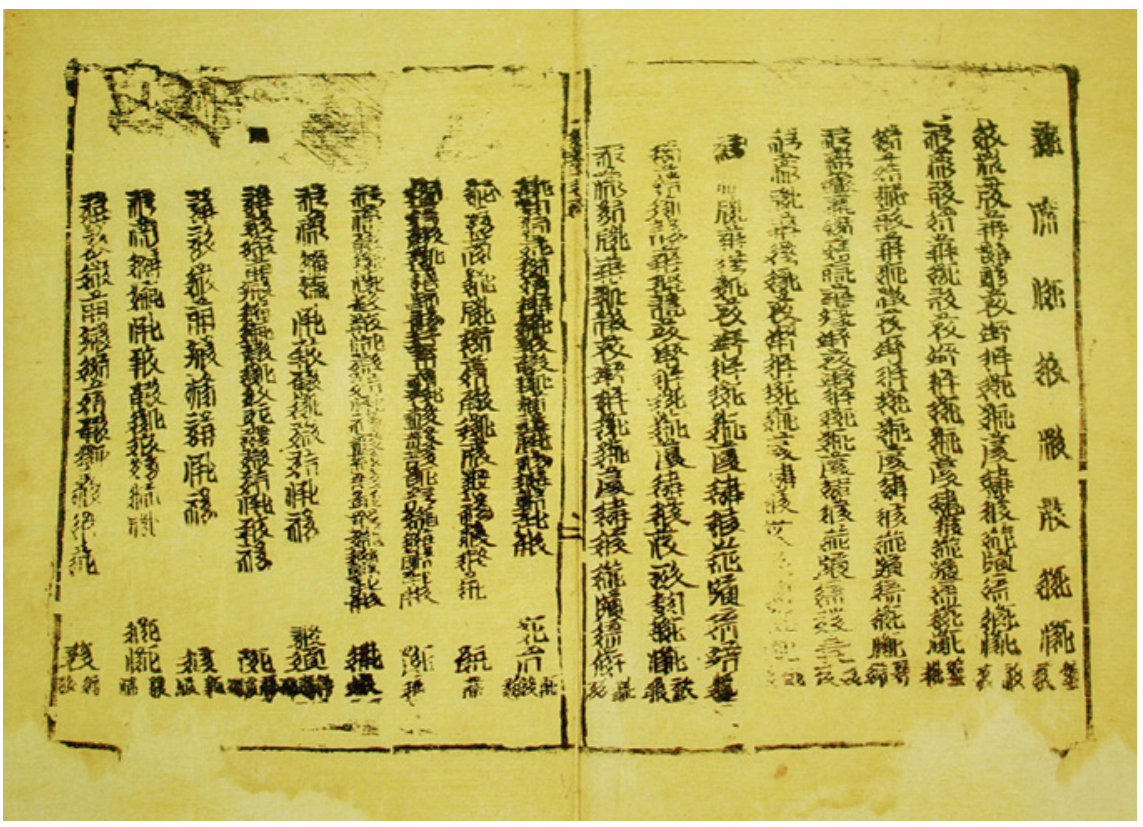

FIGURE 12 The "Proclamation of Legislations" in the Laws of Heavenly Prosperity (2)

There is no doubt that the Tanguts borrowed from the Chinese imperial laws, but the process was one of adaptive reception, rather than mechanical appropriation. The ruling elites of Western Xia by no means resorted to simply copying and pasting established Chinese legal codes. Instead, they considered the practical conditions of their own kingdom, and creatively enacted laws according to their needs.

The Laws of Heavenly Prosperity encompassed criminal laws, litigation laws, administrative laws, civil laws, economic laws and military laws. Diverse and comprehensive, it was meant to be a universal collection of all legal iterations. ${ }^{2}$ The codex not only absorbed from legal theories based on the concepts of political loyalty and filial piety, the essential philosophies underpinning the Tang and Song legal traditions, and from the effective and enforceable "Ten

2 Shi, Jinbo. "Yibu You Tese de Lishi Fadian: Xixia Tiansheng Gaijiu Xinding Lüling" [一部有 特色的歷史法典: 西夏天盛改舊新定律令]: “A Historical Law Code with Characteristics, the Tangut Revised Laws of Heavenly Prosperity” Zhongguo Falüshi Guoji Xueshu Taolunhui Lunwenji [中國法律史國際學術討論會論文集]: Proceedings of the International Conference on Chinese Legal History. Xi'an: Shaanxi People's Press, Sep. 199o; Shi, Jinbo. "Xixia Tiansheng Lüling Luelun” [西夏天盛律令略論]: “A Cursory Discussion on the Tangut Laws of Heavenly Prosperity” Ningxia Shehui Kexue [寧夏社會科學]: Ningxia Social Sciences, issue 1,1993 . 
Evils,"3 "Eight Deliberations"4 and "Five Penalties,"5 but also inherited a rich and rigorous legal system in criminal law and litigation from their rivals and neighbours in the Central Plains. In learning from the Chinese Empire, the Tanguts were as studious as innovative, and in this way, they even developed and enriched the Tang and Song laws.

Unlike the imperial laws of previous dynasties, which, for the most part, only detail the penalties for violations of the laws, the Laws of Heavenly Prosperity first expounds on what are and are not to be done, before it establishes the punishments of wrongdoings. In this regard, the Tangut law code inches closer to the form of a universal legal codex, even when compared to Tang and Song laws. On the other hand, the Tangut Empire never transcended its identity as a conventional medieval empire, for which the laws were meant to defend the imperial authority, to uphold the feudal social order and hierarchy, and as is the case in Chinese laws, to place its heaviest emphasis on traditional values of filial piety and righteousness.

The Laws of Heavenly Prosperity boasts its own distinctions, makes noteworthy contributions to the tradition of written law, and points to new conceptual and practical paradigms in and beyond medieval Chinese legal history. Through the lens of the Laws of Heavenly Prosperity, it is possible to gain a thorough understanding of the multifarious sides of the socio-economic lives of the Tangut people, and thus to further investigate the political institutions, class relations, social structures, economic systems, military organisations, religious policies and ethnic relations of this medieval Asian kingdom.

Given the paucity of Chinese primary sources on Tangut society 'in the streets' and 'on the ground,' materials in Tangut are valuable to the point of irreplaceable. Amongst all the available sources authored by the Tanguts themselves, the Laws of Heavenly Prosperity is the most concentrated, comprehensive and

3 TN: Or ten abominations, included Plotting Rebellion [謀反], Plotting Great Sedition [謀大逆], Plotting Treason [謀叛], Contumacy [惡逆], Depravity [不道], Great Irreverence [大不敬], Lack of Filial Piety [不孝], Discord [不睦], Unrighteousness [不義], Incest [內亂].

4 TN: In traditional Chinese criminal laws since the time of Zhou (enacted since Wei), the “Eight Deliberations" are the Deliberation for Relatives of the Emperor [議親], Deliberation for Old Retainers of the Emperor [議故], Deliberation for the Morally Worthy [議賢], Deliberation for Ability [議能], Deliberation for Achievement [議功], Deliberation for High Position [議貴], Deliberation for Diligence [議勤], Deliberation for Guests of the State [議賓]. These privileged conditions are the prerequisites for further discussions on possible commutations of sentences.

5 TN: Tattooing on the face or forehead [墨], amputation of the nose [劓] or feet [肞] (sometimes kneecap: [臏]), removal of the reproductive organs [宮] and death [大辟]; or, lashes [ 笞], strokes [杖], penal servitude [徒], exile [流] and death [死]. 
consequential. The discovery, translation and interpretation of manuscripts such as the Laws of Heavenly Prosperity pave new ways for historical research on Tangut society.

\subsection{Economic Regulations and Legislations in the Laws of Heavenly Prosperity}

Of the 20 volumes of the Laws of Heavenly Prosperity, volumes 15 to 19 concern economic laws. Volumes 15 and 16 are devoted to agriculture, with 19 categories and 132 items in total. Volume 15 alone contains more than 10,00o characters. Regrettably, the malignity of fortune leaves us hardly anything in volume 16. Contents on agriculture and land tax in Tangut laws dwarf those in Tang and Song codes. Volume 15, which concerns such matters as levying land taxes, cultivating barren lands, opening canals and applying irrigation, is detailed and exhaustive. The chapter on waterways, for instance, not only commands that 150 deputy supervisors and 'canal-officers' be sent along all the water routes from the Central Commander's Region to the county of Dingyuan, but also elaborates on how they should oversee the watercourses:

All the heads of canals, canal-officers, canal-supervisors and junior supervisors should proceed along the waterways in their due territories, and in overseeing the watersheds, let them take caution. In case parts of the plates and water gates are unstable, let the concerning bureau repair and reinforce them. If out of negligence or carelessness, the officers do not report such problems to the local bureau, and due to the lack of renovation and consolidation, the canals break and the water is cut off, the monetary assessments of all the resulted losses of houses, either private or state-owned, sprouts in the field, stored grains, temples and roads, as well as incurred labour and other costs will be duly calculated, the sum of which will provide the basis for the judgment of the crime and due prosecution. ${ }^{6}$

It is followed by five further items of about 6 oo characters assuring the accuracy and the standards of credit and oversight for these officials. Such detailed accounts of the plate and water gate are found perhaps nowhere else than the unique law code of Western Xia.

The Dangxiang Tanguts were originally a nomadic race on the steppe and did not cease their herding activities even after the founding of the empire. In addition, the Uyghurs and Tibetans within Tangut territories relied just as

6 Revised Laws of Heavenly Prosperity 15, p. 499. 
much on animal husbandry. In the Laws of Heavenly Prosperity, there is considerable mentioning of stock-raising in volume 19, which is divided into 13 categories and 78 items, about 13,000 characters in total (the surviving manuscript is partly damaged). Similar topics are also found scattered in other volumes. The items and word count of this topic outnumber those in the Tang laws by five and ten times, respectively. Such descriptions are also richer and more diverse than in the Tang Code. In fact, it is still possible to learn everything about how to care for animals giving births, and to reward and punish the personnel in charge:

The youngsters of the Four Herds should be counted in the prescribed manner, and the actual number should be registered. If there is a gap, then ask the people concerned to compensate for it. Each year, let the extras be given to the herdsmen. When the babies die, do not cancel the record. Do not give the foals to the stallions, but to the mares.

A hundred adult female camels are expected to produce thirty youngsters, and this should be checked by a Yingneng magistrate on the first day of April. Let a magistrate examine it and an official confirm it, and register it as newly obtained and collectively produced. Sixty youngsters are expected for two years, and the number should be met accordingly. The foals on the record should be registered in order.

A hundred mares are expected to give birth to fifty foals per year.

A hundred cows are expected to give birth to sixty calves.

A hundred ewes are expected to give birth to sixty lambs.

Yaks roam the Yanzhi and Helan mountains. The Yanzhi mountains offer excellent earth thanks to the yaks. Each year, five calves are expected from ten yaks. When deaths are compensated, real yaks should be repaid. As for the number of yaks in the Helan mountains, each year around the time of July and August, let someone honest and reliable from the imperial household be sent to examine it. Register all matured calves in the record. When there are deaths, repay by calves. In case of any violation of the law, for instance, should the yak-examiner not fulfil this duty according to the prescribed time, all concerned Senior Officials (daren), Order-bearers (chengzhi), Administrators (du'an), Clerks (antou), agents (sili) and other functionaries with titles should yield a horse as a way of punishment. For commoners, thirteen strokes await. If the yak-examiner purposefully conceals the number of calves, or if the examiner and the 
herdsmen are bribed, then an analogy to the crimes of corruption and theft is applied. In severe cases, the criminals are tried. If there is neither bribery nor ignorance, let the examiner not be sentenced, but the herdsmen punished as if in cases of theft. ${ }^{7}$

The "Four Herds" refer to horses, camels, cows and sheep. Yingneng is the title of a low-ranking official. In these items, the expected number of youngsters is properly distinguished for each animal, and the law devoted a specific passage to the examination of yak calves in Yanzhi and Helan mountains.

The Laws of Heavenly Prosperity focuses on the regulation and maintenance of storage in volume 17, in 7 categories and 58 items, about 14,000 in words in total (despite some loss and damage). The sheer number of storage laws here are more than 10 times the number in the Tang Code. For example, concerning transfers between different storage departments, there are specific rules about the number of agents and office employees, overseers (monitors) and cashiers to be dispatched by each storage house, as well as the proper procedures for local tax-collecting agencies to report taxes to the three main bureaus:

All the taxes and alcohol taxes on each day are collected to the treasury in capital Zhongxing at night; land taxes from the five prefectures are collected once per month. Such information is to be reported to the three bureaus, and should be regulated according to another law of supervision. ${ }^{8}$

The chapter on the delivery of supplies details the procedures, management and registration of the retrievals and expenditures of supplies from the storages:

All the officials in charge of the storages, their paid, distributed and slaughtered livestock, and grain of government ownership, the receipts of such incomes and expenditures should be urged at speed by the personnel of the storages. From the day of the reception of government-owned livestock and grain, receipts should be available within ten days. The bureaus in charge of the storages should make the calculation, and are prohibited from soliciting briberies. If any violation of the law is discovered, or if the bureau's officials do not urge the people, or if they do not issue the due receipts, or if they solicit bribes, delay the time, and in this

7 Revised Laws of Heavenly Prosperity 19, pp. 576-577.

8 Revised Laws of Heavenly Prosperity 17, p. 529. Some revisions have been applied to the original text. 
way, exceed the time limit, the concerned administrators (du'an), clerks (antou), and agents (sili), overseer of room and board, head of the storage and the cashiers will be duly prosecuted for their delay and negligence of public affairs. Those who furthermore accepted briberies will be prosecuted on the charge of corruption, which will then be compared to the charge of delay and negligence of public affairs, and whichever is more severe will be the charge to be applied. ${ }^{9}$

There is also a section on urgent necessities and those prohibited from governmental purchase, which clarifies the procedures of purchasing items for governmental use and regulations of their supplies and transactions:

In case each bureau should dispatch men to purchase diverse products, miscellaneous properties and such things as peat, as well as temporary needs for livestock and produce, the transaction could only take place if both parties are willing. It is strictly prohibited to purchase by force. Should such an instance occur, the senior officials (daren), order-bearers (chengzhi), administrators (du'an), clerks (antou), and the other employees in political office will be prosecuted on the charge of forced transaction: the price at which the officials forcefully bought the products will be compared to the original price, to calculate the loss incurred to the seller. Then the concerned individual should be sentenced to at least one year in prison. If, moreover, an official should flaunt his political power to commit fraud in a forced transaction, such as to appropriate for private use or to lower the price of the products and thus incur loss to the owner of the properties, the crime will be deemed to be one level below that of theft. If out of personal greed the official consumes it in private, even though he allegedly purchased it for the public and thus lowered the price, the gap will be calculated, and he will be prosecuted on a charge one level further below that of appropriation for private use. ${ }^{10}$

The section on the transmission and departure of stored properties sets the procedures and times for the director of the storage to transfer and examine such products as grains, gold, silver, bronze, threads, coins, paper, vases, grass, oil, alcohol, medicine, linen, butter, coal, thick and thin liquor ferments, rush used as lamp wick and raw silk. It records the precise amounts of these supplies to be consumed, to the extent that it lists more than 200 names of

$9 \quad$ Revised Laws of Heavenly Prosperity 17, p. 536.

10 Revised Laws of Heavenly Prosperity 17, p. 540. 
herbal medicine in its discussion on the consumption of raw medicine. ${ }^{11}$ That a 'national,' imperial legal code contains such meticulous details demonstrates the fullness and thoroughness of the Tangut code, and the Tanguts' attachment of great importance to the regulation of its own economy. Historians also derive from these primary sources the major goods and necessities, and the state of the manufacturing industry in the Tangut Empire. The laws are also instrumental to the general study of Tangut society.

In the same category was found a list of rules for government-regulated pawning:

In government-owned pawnshops, properties are allowed to be pawned only if the capital and the interest are calculated to be cancelled out. Nothing should be pawned without such careful calculation. If there is any violation of the laws, the concerned individuals will be condemned on the charge of corruption and violation of law. Among those who have not accepted bribery, officials should yield a horse as punishment, while commoners should receive thirteen strokes. The gap between the capital and the interest should be repaid by the owner of the pawnshop. Should the junior overseers of the shop and other great officials including the premier use their political power to force the transaction, to not consider the capital and the interest of the government-owned pawnshop, or to pawn only because of wealth; also let the concerned individual forcing the pawning repay the capital, and be prosecuted according to the prescribed law. ${ }^{12}$

To the legal issues of debt, market transactions and transaction taxes, the Song lawmakers devoted about 13 items in volume 26 in the Compendium of Song Laws, whereas in the Tangut Laws of Heavenly Prosperity the entire volume 18 is devoted to business transaction and taxes, divided into 9 categories and $5^{6}$ items. They encompass a wide range of topics, including sales taxes, shipping, liquor ferments, salt pond, dispatch of overseers (monitors), and lowering taxes for foreign trade. One example is an account of the 12 levels of fines for unlicensed productions of liquor ferments, varied according to the monetary values of the ferments produced. First-degree crimes in ferment-production even leads to the sentence of imprisonment for life:

11 Revised Laws of Heavenly Prosperity 17, pp. 547-556.

12 Revised Laws of Heavenly Prosperity 17, p. 542. 
All men are prohibited from producing liquor ferment in secret. If a violation of the law is uncovered, let the total of ferments produced be weighed. Within a thread of ferments, the principal offender deserves thirteen strokes, and the accomplices ten strokes; between one to two threads, the principle criminal is to be sentenced to prison for six months, the accomplices three months; between two to four threads, the prime culprit will be imprisoned for a year, and the accomplices six months; between four to six threads, the principle will be imprisoned for two years, and the accomplices one year; between six to eight threads, the principle will be imprisoned for three years, and the accomplices two years; between eight to ten threads, the principle will be sentenced to four years, and the accomplices three years; between ten to twelve threads, the principle will be sentenced to five years, the accomplices four years; between twelve to fourteen threads, the principle will be sentenced to six years, and the accomplices five years; between fourteen and sixteen threads, the principle will be sentenced to eight years, and the accomplices six years. Between sixteen and eighteen threads, the principle will be sentenced to ten years, and the accomplices eight years; between eighteen and twenty threads, the principle will be sentenced to twelve years, and the accomplices ten years. Above the quantity of twenty threads, all the principle criminals who intended the production will be imprisoned for life, and the accomplices for twelve years. If the buyer was aware of the illegality of the transaction, then his guilt is one level lower than that of the accomplice. If the buyer is ignorant, then let no charge be brought against him. To those who report the name of an offender, let there be reward: five threads are rewarded to the reporter of a crime in the range from punishment by strokes to six months of imprisonment; ten threads rewarded for the level of one year of imprisonment; twenty threads rewarded for the level of two years of imprisonment; thirty threads rewarded to the level of three years of imprisonment; forty threads rewarded to the level of four years of imprisonment; fifty threads rewarded to the level of five years of imprisonment; sixty threads rewarded to the level of six years of imprisonment; seventy threads rewarded to the level of eight years of imprisonment; eighty threads rewarded to the level of ten years of imprisonment; ninety threads rewarded to the level of twelve years of imprisonment; a hundred threads rewarded to the level of life imprisonment. Let the rewards be obtained from the criminals who committed various degrees of crimes. In case a price of the liquor ferments has already been applied, 
let the price of the time be adopted for calculation, and let them be confiscated to the palace. ${ }^{13}$

The Tangut Empire was a main exporter of salt, one of the most critical components of its trade and economy. It is therefore no surprise that this volume painstakingly details the prices and taxes of salt:

Concerning all salt dealers, the salt from the $W u$ Pond should be sold at the price of a hundred and fifty maces per dou; for salt extracted from other salt ponds, the price is a hundred maces per dou. Let all taxes be levied and leave no tax evaded. In case of a violation of law, the amount of taxes evaded is to be calculated, and the concerned individuals will be prosecuted on the charge of theft. ${ }^{14}$

Furthermore, there are as many as 22 items in the discussions on pawning and pursuit of debt and interest in the third volume. Here is a piece of legislation on pawning:

Pawning should only occur if both parties, the owner of the property to be pawned and the pawnbroker, are perfectly voluntary. In case that the pawned property is of greater value than the loan received, it is possible to demand that the property not be sold once the principle equals the interest, provided there is a witness; in the opposite case, if the value of the pawned property is less than that of the loan, it is possible to set a date, beyond which the pawnbroker would be allowed to sell the property. The two parties may conduct such plans upon mutual agreement. In addition, if the discussed and set date is not made clear to the pawning party, and the principle and interest are equal, but the property owner does not come to reclaim his belonging, the shop owner may sell it as he wishes. If the property owner violates the law in the litigation, his punishment would be a horse if he is an official, and thirteen strokes if a commoner. ${ }^{15}$

But to pawn more valuable assets such as houses and lands, there are more specific laws and regulations to consider:

13 Revised Laws of Heavenly Prosperity 18, p. 564.

14 Revised Laws of Heavenly Prosperity 18, p. 566.

15 Revised Laws of Heavenly Prosperity 3, p. 186. 
There should be no confusions or disagreements between the parties about to pawn houses and lands in exchange for loans. Let them estimate the total value of the sprouts and houses in the field, see to it to be written in a signed record, and pay back once the money is in place. Moreover, if interest arises from the sum of money, and the houses and lands are returned to the owners, let the interests, and the prices of the houses, sprouts in the fields, and the fruits born be re-calculated. No extra interest should be demanded once the principle and interest should equal. If there is a delivery of interest against the law when the land and houses do not belong to the owners, officials will pay the penalty of a horse, and commoners will suffer thirteen strokes. ${ }^{16}$

There are also specific rules to follow when it comes to borrowing and lending, pressing your debtors for payments, and covering debt by means of labour:

Throughout the country, concerning public loans of money and grains, the interest rate of each thread should be below five maces, that of each gong of grain should be below a gong; interests should be set voluntarily, and no further increase is allowed. If the principle equals the interest, but there is no repayment, the relevant party should report to the government to urge the debtor to pay the loan back to the creditor. If the debtor is unable to pay it, urge the ones who went along to repay the loan. If neither were those who went along able to cover the sum, let the two kinds of men's wives, daughters-in-law and unmarried daughters pawn their belongings in exchange for money, in order to pay the debt. If the ladies receive insufficient money from pawning, or if they have nothing to pawn, the current owner should pay the debt. If he is unable to, and he received the loan before he divides his meals, let his families contribute to the payment; if the debt is incurred when the meal is not divided, let him not enter the house. If neither is possible, let the borrower pay back in the form of physical labour. After the principle equals the interest, he is still not to obtain payment of debt from the interest or the grains. If there is any violation of the law, the officials are punished a horse, commoners thirteen strokes, and all the debts are to be paid on that exact same day. As for those who went along to claim the loans, they should, if they are able to, contribute to the repayment. ${ }^{17}$ text.

17 Revised Laws of Heavenly Prosperity 3, pp. 188-189. 
These legislations on commercial activities are proofs of a highly advanced and well-managed economy in the Tangut Empire. It also reveals information on the situations of debt and pawning in the regime, increased regulations of transactions at home and trade from abroad, as well as tremendous influence of Chinese economic laws and of Song-Tangut trade.

To a large extent, such primary texts from the Tangut legal codex, the Laws of Heavenly Prosperity as presented above, are critical sources of information on Tangut society and economy. They are of paramount importance, especially because they filled the want, if not vacancy, of archival materials on the Tangut economy. But since these items were established according to legal norms, it is still necessary to consult economic documents that directly reflect social realities in order to paint a more detailed and vivid portrait of the Tangut economy.

\section{2 Economic Documents in the Corpus of Tangut Social Documents}

The social and economic documents excavated in the past century have caught the attention of academia, for these realistic and vivid sources are enough to enrich, and even to evolve studies of economic history, in general. For instance, the many social documents discovered in the Dunhuang cave made a priceless contribution to historical research on the economy of the medieval world centred around the Tang imperium. However, it is unfortunate that little progress had been made in the economic histories of Song, Liao and Jin, due to the lack of social documents as primary sources, until the excavation of the Khara-Khoto manuscripts, which helped launch Tangutology as a modern discipline. Published in the 199os, these once hidden manuscripts have come to public light and greatly transformed Tangut studies and allied fields. The discovery and publication of social documents, in particular, gave birth to "Tangut social document studies" as a viable and productive subfield in Tangut Studies. This sizable collection of social documents added a new library of invaluable materials to a field of study long plagued by the deficiency of primary sources. As if a gift from heaven, this wealth of historical documents brought great joy to the scholars, for it is critical not only to studying Tangut society and economy, but also to gaining a more accurate understanding of the close interactions between states such as the Chinese, Khitan and Jurchen dynasties.

Barely known to the world, Tangut social documents did not always feature prominently in academic research. There were only 15 known Chinese pawning contracts before the 1990s, obtained by British archaeologist Aurel Stein. Amongst these, only 11 are still legible, of which the numbers of the pawned 
properties could be identified. ${ }^{18}$ It was also known that 2 Tangut transaction and loan contracts emerged from the Khara-Khoto site. Pyotr Kuzmich Kozlov (Пётр Кузьми́ч Козло́в) brought them home, where they were studied and published by the renowned Soviet Tangutologist Evgenij Ivanovich Kychanov (Евгений Иванович Кычанов)..$^{19}$ Though small in quantity, the information contained in these precious manuscripts reflects the fascinating realities of Tangut economic lives and activities. The early study and publication of these texts initiated the research on Tangut social documents. But as said previously, due to the limited types and numbers of social documents, it did not then seem likely that the path to a thorough investigation of the Tangut economy was underway.

Then came the good news. In collaboration with Russian experts on the publication of the Russian Collection of Khara-Khoto Manuscripts in Chinese, we found a pile of unregistered social documents at the Institute of Oriental Manuscripts (IOM) in St. Petersburg. It turns out that although Russian experts had already sorted out a group of social documents, most of which we identified in 1997 and 2000 from 110 boxes of manuscript fragments, as if sifting gold through sand, some other documents were used as sutra covers-some had their words exposed, whilst others had already fallen off. We registered and photocopied all of them, which counted up to 1,000 numbers and 1,500 pieces. Amongst them, most are written in Tangut, others in Chinese, including household and military registers, accounts, contracts, official documents and epistles. These precious primary sources outnumber even those found in the Dunhuang Grottoes. Moreover, the proportion of completely legible manuscripts is also impressive. ${ }^{20}$

In recent years, more Tangut and Chinese social documents have been found and stored in Khara-Khoto, Dunhuang, Wuwei, Yinchuan and the National Library of China.

18 Chen, Guocan. “Xixia Tianqing Diandang Canqi de Fuyuan” [西夏天慶典當殘契的 復原]: “Restoration of the Remnant Pawning Contracts from the Era of the Heavenly Celebration (Tianqing)" in Zhongguoshi Yanjiu [中國史研究]: Journal of Chinese Historical Studies, issue 1, 1980. For the original, see Maspero, Henri. "Les Documents chinois de la Troisième Expédition de Sir Aurel Stein en Asie Centrale" London: Trustees of the British Museum, 1953.

19 Кычанов, Е.И. Тангутский документ 117ог. о продаже земли, "Письменные памятника Востока.Ежгодник. 1971” М., 1974, pp. 196-203. Е.И. Кычанов Тангутский документ о займе под залог из Хара-хото Письменные памятника Востока.Ежгодник. 1972, М., 1977, pp. 146-152.

Russian Collection of Tangut Manuscripts, vol. 12-14, 2006-2011. 
The value of the Tangut social documents mentioned above is obvious to experts in the humanities and social sciences in general, and especially to those interested in historical social studies. They are the gateway to research on the concrete social realities of the Tangut regime. To compile, translate and study them, therefore, leads to not only progress in Tangut history but also the enrichment of historical references to the societies of Song, Liao and Jin empires, whose residents lived contemporaneously to the Tanguts. It is therefore no exaggeration that this collection was the key to the theretofore impenetrable gates of Tangut society, with which it now seems possible to create new paradigms and subfields on the increasingly fertile soil of Tangut Studies.

In this book, I try to recreate a sketch of Tangut populations, lands, taxes, commodity prices, loans, transactions, leases, exchanges and mutual supports, based on substantial translations of Tangut social documents and resources from Tangut laws and other materials. The goal is to further analyse the organisations of Tangut communities, basic units of the military, as well as agriculture, animal husbandry and manufacture, and in this way, reach a more refined perspective on the Tangut society. In the following section, I will present a brief introduction to the Khara-Khoto social documents and current research on these historical sources.

\subsection{Tangut Household Registers and Demographic Records}

Household registers and population records number to more than 110 pieces, including brief household registers, self-reported shoushi (records on registered residence, population, ownership of land, and taxation reported by families themselves), liliu (unit of distance, equivalent to the Chinese $l i$ ) registration, and household registers of male and female populations. These materials preserve the most authentic information on the demographics in the Khara-Khoto area under Tangut rule. For example, household register Инв. No. 6342-1, as long as $300 \mathrm{~cm}$, contains a brief account of nearly 30 households, including the demographics, the name of the patriarch of the house, and each family member's name, gender, age and relationship to the patriarch. These records provide us with enough data to carry out further analysis of family types, populations, male-to-female gender ratio, residence and marriage status of the Tanguts in the Khara-Khoto area, and to confirm the occurrences of Fan (Tangut)-Han (Chinese) intermarriage, polygamy, and cross-cousin marriage. ${ }^{21}$ Also available are data on household ownerships of lands and livestock, and

21 Shi, Jinbo. “Xixia Huji Chutan: 4 Jian Xixiawen Caoshu Huji Shiyi Yanjiu” [西夏戶籍初 探4 件西夏文草書戶籍譯釋研究]: “Some Initial Discussions on the Interpretation of Four Tangut Household Registers in the Cursive Script" in Minzu Yanjiu [民族研究]: Ethno-National Studies, issue 5, 2004. 
with Laws of Heavenly Prosperity as a point of reference, we can inquire into the modes of organisation at the village level, and other matters such as the close relationship between Tangut household registers and the military chao system. The Laws of Heavenly Prosperity mandates that all families report promptly any demographic change in their houses to the government, to avoid falsities and confusions, in order to keep the "records clean, and updated every three years."22 These documents suggest that the Tanguts had indeed formulated, established and enforced a robust institution of household registration. The discovery of these sources therefore filled the vacancy of Tangut household records and now assuredly provides the best primary sources to conduct research on Tangut family and society.

\subsection{Tangut Land Taxes}

More than 140 registers of Tangut accounts of land taxes survived, of which there are accounts of farming, grain loans, hay and forage loans, liliu grain loans, poll taxes, irrigation taxes, warranties for grain debt, accounts of grains owed to the government, and deficit supply accounts. Khara-Khoto Инв. No. 5949-33, 34, 35, 36 and 37 , for example, are accounts of farmlands. One of the records, which measures land size by the amount of seeds sowed, records the farmlands owned by 20 households within 1 liliu of distance. Another example is Инв. No. 48о8, an account of grain loans by liliu, a long roll of 255 lineswith the 6 additional fragmented lines, it would be 261 in total — stitched by 4 sections. The first and second are statistics on grain taxes; the third and fourth are accounts of grain taxes paid. All of them indicate that the Tanguts resorted to a fixed agricultural taxation system based on the amount of land owned. Historians could also infer from these data the types of grains substituted for taxes, and the ratio between barley and wheat as taxes. For instance, Инв. No. 1755-4, an account of grain taxes by household, includes both the quantities of land in $m u$ and of grains, from which it is possible to calculate the land taxes in the form of grains to be 1.25 litres per $m u$ in the Khara-Khoto area. Similarly, Инв. No. 4067 and 5067 are both accounts of peasants' payment of land taxes, labour and hay based on their ownership of land. Some of them even recorded the location and four borders of their land. Another booklet, Инв. No. 8372, collects statistics based on units of liliu. There is also Khara-Khoto Инв. No. 4991, a record of poll taxes that assembles data on the demographics and grain taxes of 59 households based on the number of family members-males, females, adults and children - in each household. This is a kind of tributum capitis ("capitation tax" or "head tax"). It is obvious from the data that the standard tax rate was fixed, despite gender differences, albeit with reasonable variations 
between the adults and the underage: 3 dou per adult versus 1.5 dou per child, by all means a heavy poll tax. ${ }^{23}$ Besides, there were also "water taxes" such as the irrigation tax record Инв. No. $1454-2 \mathrm{~V}$, which mentions not only the areas and due taxes of three irrigated fields, but also the specific locations of these fields. It belongs to a group of special taxes in Western Xia. The tax on water for agricultural use subtly reveals the dire situation of irrigation in Khara-Khoto.

\subsection{Tangut Accounts of Grains and Properties}

Apart from grain accounts, there were amongst the excavated manuscripts some fragmented statistical records of grains and other properties, which disclose some curious materials otherwise unfound in the aforementioned long rolls. For example, some were accounts of subsidies to soldiers in the camps. Others were records of grains assigned to local residents to transport. They add to our existing materials and point to new ways to study the Tangut society.

These documents also make records of iconic properties about which, nonetheless, we knew little in the past. For example, some texts mention the words "Fan cloth" and "Han cloth," suggesting that the Tanguts had their own textile industry before entering traditionally Han territories and continued to manufacture cloths 'with ethnic characteristics,' perhaps to complement Chinese cloths, well into the final years of the empire. This discovery corrects our previous assumption that the Tanguts had been ignorant of textile manufacture until they settled down in the northwest and learnt from their more industrially advanced Chinese neighbours.

\subsection{Tangut Commercial Documents}

Commercial documents number up to go registers, of which are accounts of properties sold and purchased, transaction prices, grain prices, grain loans, interest of grain loans, transaction taxes, money and properties, as well as other financial statistics.

It is now possible to work out the commodity prices in the Tangut Empire. Transaction accounts Инв. No. 1219-1, 2 and 3, for example, reveal the price of sheep; Инв. No. 3858 tells us the price of silk; Инв. No. 4696-8, an account of alcohol sales, features quite a few transaction records, from which we could infer that the price of rice wine per dou was roughly equivalent to that of 1.5 dou of barley. Nor is it impossible to compute a price directly: the remnant

23 Shi, Jinbo. "Xixia Nongye Zushui Kao-Xixiawen Nongyeshui Wenshu Yishi” [西夏農業 租稅考: 西夏文農業稅文書譯釋]: “Agricultural Taxes in Western Xia: Interpretations of Tangut Documents of Agricultural Taxes” Lishi Yanjiu [歷史研究]: Historical Research, issue 1,2005 . 
pages, Инв. No. 1366-6, 7, 8 and 9, record the prices of alcohol to be 250 maces per dou.

Other documents are accounts of sales taxes. Khara-Khoto Инв. No. 6377 tells us that the transaction tax rate of purchasing a sheep was $5 \%-10 \%$ of the original price, whereas that of a cow was as much as $8 \%{ }^{24}$

Still, others are accounts of money and grains in both Tangut and Chinese, such as Khara-Khoto Инв. No. 2851, essentially a thirty-page book, which has on its back the following grain accounts: "153 dan, 7 dou, 2 sheng, 8 ge" on the first page, "grains 50 dan, 1 dou, 3 sheng, 3 ge and a half" on the second page, "grains 175 dan, 1 dou, 6 sheng" on the fourth page, "584 dan, 1 dou, 9 sheng, 2 ge" on the seventh page, and "grains 529 dan, 2 dou, 1 sheng, 6 ge and a half" on the eighth page, with each item followed by more detailed comments. ${ }^{25}$

\subsection{Tangut Contracts}

Thus far, we have identified and preserved contracts-as many as 150 registers and 500 pieces, 200 of which are dated to specific eras. Only a handful of Tangut contracts was known in the past: 15 fragmented pawning contracts written in Chinese and 2 Tangut contracts published by Russian experts. The newly discovered batch of materials, on the other hand, are impressive not only in quantity but also in variety, including contracts of grain loans, property loans, monetary loans, land sale, transaction of human beings and livestock, land lease, employment of human and animal labour, as well as communal contracts. In any sense, the Tangut contracts are comparable, if not superior to those discovered in Dunhuang. Zhang Chuanxi, an expert on contracts, once commented on the scarcity of early Chinese contracts, "Contracts dated between Western Han and Yuan Dynasties are rare, so every single one of them is a treasure." ${ }^{26}$ It is therefore no exaggeration that our collection of Tangut social contracts is a priceless treasure-trove.

\subsubsection{Loan Contract}

Contracts of grain loans feature most prominently among loan contracts, numbering up to 110 registers and 300 pieces. They contain detailed information on

\footnotetext{
24 Shi, Jinbo. “Xixia de Wujia, Maimaishui he Huobi Jiedai” [西夏的物價、買賣稅和貨幣 借貸]: “Commodity Prices, Transaction Taxes and Loans in Western Xia” in Songshi Yanjiu Lunwenji [宋史研究論文集]: A Collection of Papers on Song History. Shanghai: Shanghai People Publishing House. July 2008.

25 Russian Collection of Khara-Khoto Manuscripts 13, pp. 120-131.

26 Zhang, Chuanxi (ed.). Zhongguo Lidai Qiyue Huibian Kaoshi [中國歷代契約彙編考釋]: Studies and Interpretations of Contracts in All Chinese Dynasties. Beijing: Peking University Press, 1995, p. 7.
} 
the time of the loan, the names of the borrowers and the lenders, the types and quantities of the grains loaned, interest rates, expected duration and frequency of repayments in instalments, penalties of the debtor in case of default or a breaching of contract, as well as the signatures, finger stamps and numerical notations of both parties. These contracts of grain loans vary greatly in terms of their types and extensiveness. Many of them were usurious loans at unstable times. Once again, with comparative and connective reference to Laws of Heavenly Prosperity, we are able to analyse the terms of grain loans in Western $\mathrm{Xia}$, and in this way, to refine our perceptions of the living standards, economic conditions and social inequalities at the bottom level of the Tangut society. ${ }^{27}$

\subsubsection{Transaction Contract}

Transaction contracts concern the transfers or sales of land, livestock, house, and even human beings. At least 12 land lease contracts in acceptable conditions have been found in Khara-Khoto, with all necessary information such as the amount, price, arable fields, irrigation, agricultural taxes and the four borders of the land sold. They are undoubtedly the best primary sources to consult in research on Tangut agriculture and transfer of arable land. ${ }^{28}$

In addition, 20 of the Khara-Khoto manuscripts were transaction records of livestock, and similar contracts were found in the city of Wuwei. All of them are dated to the late imperial ages, of which about ten remain well-preserved. They reflect the realities of the Khara-Khoto and Wuwei economies during this period, through the sales of camels, horses and cows, in light of fluctuating prices of these steeds and livestock. Other records have to do with the pawning and mortgaging of animals. ${ }^{29}$

Three of the Khara-Khoto contracts concern terms of agreements on the transaction of actual human beings, an accurate portrayal of this particular social reality of the Tangut Empire. They show that although the Tanguts entered what some historians still refer to as the 'feudal' age, there were still remnants of slavery, though in the moderated forms of shijun (acquired

27 Shi, Jinbo. “Xixia Liangshi Jiedai Qiyue Yanjiu” (西夏糧食借貸契約研究): “A Study of Tangut Contracts of Grain Loans" in Zhongguoshehuikexüeyuan Xüeshu Weiyuanhui Jikan (中國社會科學院學術委員會集刊): A Collection of Papers by Fellows of the Chinese Academy of Social Sciences, issue 1. Beijing: Social Sciences Academic Press, March 2005.

28 Shi, Jinbo. “Heishuicheng Chutu Xixiawen Maidiqi Yanjiu” [黑水城出土西夏文賣地契 研究]: “A Study of Tangut Contracts of Land Sales Excavated in Khara-Khoto" Lishi Yanjiu [歷史研究]: Historical Research, issue 2, 2012.

29 Shi, Jinbo. “Xixiawen Maichuqi he Guchuqi Yanjiu” [西夏文賣畜契和雇畜契研究]: “A Study of Tangut Contracts of Livestock Transaction and Employment" Zhonghua Wenshi Luncong [中華文史論叢]: Series on Chinese Literature and History, issue 3, 2014 (a). 
through military) and nupu (domestic servants) till the very end of its history. These documents tell us much about the bottom level of the Tangut social hierarchy, a kind of knowledge impossible to acquire through the reading of archives, annals and political texts. ${ }^{30}$

\subsubsection{Land Lease Contract}

The long roll registered as Khara-Khoto Инв. No. 5124 features 8 Tangut land lease contracts dated to the late Tangut period of Tianqing (1194-1206), which for the first time reveal the secrets of the living standards and conditions for ordinary Tanguts, lease and cultivation of arable land, and how religious establishments and temple authorities in Khara-Khoto encroached upon farmlands. ${ }^{31}$

\subsubsection{Employment Contract}

The labour 'employed' came either from humans or livestock. Only one single contract of human employment is still preserved intact-rare, as people say, as the hair of a phoenix and the horn of a unicorn. And this is not an exaggerated metaphor, because nothing of its kind remains of Song, Liao, and Jin, regimes contemporaneous to Western Xia. This manuscript therefore almost single-handedly fills the gaps in Chinese labour contracts of the 11th-13th centuries. Registered as Инв. No. 5949-32, this document is dated to 1219 of the Guangding era. Still legible are the time of signing, the names of the labourers employed, the employer, wage, requirements, and terms of agreements and penalties reserved for the employed, in case the contract was breached and the promise reneged. Then both parties involved in the agreement, together with the witness, gave their signatures and finger stamps. The format of this contract is therefore accurate and complete. Though admittedly a minuscule record of a specific case, this piece of contract allows us to peek into the modes and orders of Tangut agriculture. It also indicates that the Tanguts both imitated and simplified Chinese labour contracts. ${ }^{32}$

30 Shi Jinbo, 2014 (b).

31 Shi, Jinbo. “Heishuicheng Chutu Xixiawen Zudiqi Yanjiu” [黑水城出土西夏文租地契 研究]: “A Study of Tangut Contracts of Land Lease Excavated in Khara-Khoto” Wu Tianchi Jiaoshou Bainian Danchen Jinian Wenji Papers [吳天墀教授百年誕辰紀念文集]: Essays Dedicated to the Hundredth Year Anniversary of Professor Wu Tianchi. Chengdu: Sichuan People's Publishing House, Nov. 2013.

32 Shi, Jinbo. “Heishuicheng Chutu Xixiawen Gugongqi Yanjiu" [黑水城出土西夏文雇 工契研究]: “A Study of Tangut Contracts of Employment Excavated in Khara-Khoto" in Zhongguo Jingjishi Yanjiu [中國經濟史研究]: Research in Chinese Economic History, issue 4, 2016. 
A long roll of contracts registered as Khara-Khoto Инв. No. 5124 reveals a curious phenomenon. Three contracts of livestock transaction are each followed by a contract of livestock employment - to 'employ' an animal is, basically, to rent it. We know also that the large-sized livestock concerned in the contracts had just been purchased from impoverished peasants. It is not difficult to infer from these contracts that the Pudu Temple in Khara-Khoto engaged in the sketchy business of purchasing large livestock from grain-deprived peasants at lower prices, and immediately leasing them to needy peasants at higher prices. In this back-and-forth extraction from the poor, the dealers profited enormously. ${ }^{33}$ There were additionally some more specific contracts of livestock employment, such as Khara-Khoto Инв. No. 19-2, which concerns the temporary loan of five camels, and thus has little to do with the transaction of livestock.

\subsubsection{Contracts of Exchange and Mortgage}

Some contracts found in Khara-Khoto were signed by two individuals with the intention to exchange livestock, who agree that any gap in price would be filled in by the appropriate amount of grains. Contract Инв. No. 4195, for instance, uses the word "exchange" to describe the transaction of livestock, but "add" and "pay" for the supply of grains. Other contracts at times replace these expressions with "sell." Rare amongst excavated manuscripts, and much more complicated than the mere selling and purchase of livestock, this type of contract reflects the diverse economic lives of the Tanguts.

Khara-Khoto contracts Инв. No. 2996-1 and Инв. No. 4079-1 seem to suggest that farmers sometimes had to mortgage their livestock in order to obtain the desired loan of grains. Economic activities such as these, at once borrowing and mortgaging, are also more complex than regular contracts of grain loans. The two contracts demand that, if grains and interests were not paid back in full after autumn, the livestock would have to be foreclosed-taken possession as a result of the mortgagor's failure to keep up his payments. In this way, the lender is guaranteed a high level of financial security. There have been found in Khara-Khoto at least 8 pieces of contracts that both loan grains and mortgage livestock, which are still subtly different. In short, this is a diverse and precious collection of contracts.

\subsubsection{Communal Contracts}

Two pieces of communal contracts were found in Khara-Khoto, equivalent to the "community and neighbourhood contracts" (sheyi) in Dunhuang. These 
documents show the many ways the Tangut folks gathered, organized and supported themselves at the grassroot level. Among them is Инв. No. 5949-31, first signed in 1218. It records the rules and regulations of communal activities agreed upon, established and dutifully obeyed by all members of the societal organisation. A basic sense of equality between all involved members permeates this arrangement. The names seem to suggest that most active members were Han Chinese, though there were also participating Khitans. From the perspective of interactions between ethnic groups, these Tangut communal contracts shed a new light on Chinese communal history. It is in this broad sense that the two pieces of Tangut communal contracts are said to have filled the gap in 12th century communal records. Khara-Khoto Инв. No. 5949-31 is particularly well-preserved and of great value from the perspective of the history of books and manuscripts. ${ }^{34}$

\subsection{Economic Documents in Chinese}

Apart from the Tangut social documents excavated in former Tangut territories, there are also, quite expectedly, manuscripts in Chinese. Though less numerous, the Chinese documents are also varied and valuable. And to Chinese scholars such as myself, they are ready for interpretation without any major linguistic hurdles.

Of the Chinese documents, most were found by Kozlov in Khara-Khoto. Amongst them are an account of timber taxes in $1171 \mathrm{AD}$ (2nd year of Qianyou), a loan contract dated to 1163 (15th year of Tiansheng), a mortgage loan contract by Linghu E dated also to 1163 (15th year of Tiansheng), a grain-pawning contract by Pei Songshou dated to sometime between 1194 and 1206 (Tianqing era), a sale contract of a bakery shop by Li Chungou and others dated to January of 1222 (12th year of Guangding), as well as correspondences on land sale, a land-pawning contract, a monetary loan contract, a contract of clay payment, flax, old bags and accounts of income and payment.

The British Museum also holds a certain number of Khara-Khoto documents thanks to donations by Stein. Amongst them are Chinese economic documents such as Pei Songshou's grain-pawning contract and accounts of hay.

Quite a few Chinese economic documents have been excavated in the north zone of the Mogao caves and are now preserved at the Dunhuang Academy. One of them is Weiming Fabaoda's land sale and grain loan contract.

34 Shi, Jinbo. "Heishuicheng Chutu Xixiawen Zhonghui Tiaoyüe (Shetiao) Yanjiu" [黑 水城出土西夏文眾會條約(社條) 研究]: “A Study of Tangut Communal Contracts Excavated in Khara-Khoto" in Xixiaxue [西夏學] Tangut Studies, issue 10. Shanghai: Shanghai Ancient Books Publishing House, 2014 (c). 
Other Chinese economic documents such as IOUs (documents acknowledging debt) have been unearthed and identified in Wuwei, along with manuscripts in Tangut, as well. Some of them are today preserved at the Museum of Gansu.

The Chinese and Tangut economic documents are best studied in comparison with each other. It is most productive to consult the content of both simultaneously in scholarly research. In doing so, we not only elevate their importance in their respective traditions, but also benefit the development of Tangutology as a field of study. 